Volume 13

Issue 3 Critical Genocide and Atrocity

Prevention Studies

$12-20-2019$

\title{
Film Review: Operation Finale
}

Melanie O'Brien

University of Western Australia

Follow this and additional works at: https://digitalcommons.usf.edu/gsp

\section{Recommended Citation}

O'Brien, Melanie (2019) "Film Review: Operation Finale," Genocide Studies and Prevention: An International Journal: Vol. 13: Iss. 3: 178-180.

DOI:

https://doi.org/10.5038/1911-9933.13.3.1683

Available at: https://digitalcommons.usf.edu/gsp/vol13/iss3/19

This Film Review is brought to you for free and open access by the Open Access Journals at Digital Commons @ University of South Florida. It has been accepted for inclusion in Genocide Studies and Prevention: An International Journal by an authorized editor of Digital Commons @ University of South Florida. For more information, please contact digitalcommons@usf.edu. 
Film Review: Operation Finale

\author{
Melanie O'Brien \\ University of Western Australia \\ Perth, Australia
}

Operation Finale

Director: Chris Weitz

USA, 2018

Reviewed by Melanie O'Brien

University of Western Australia

Adolf Eichmann's capture is undoubtedly one of the most famous criminal captures of history. A high-ranking, bureaucratic Nazi who engineered the Final Solution, Eichmann fled to Argentina after the end of World War II. Argentina became a haven for Nazi war criminals, protected by a right-wing government. Attempts by Germany to extradite from Argentina Dr Josef Mengele, who had conducted medical experiments on camp prisoners, were unsuccessful.

In 1958, Israel's intelligence agency, Mossad, received a tip that Eichmann was living in Argentina. It was not until 1960 that Mossad acted on this and conducted an operation to capture Eichmann and bring him back to Israel to stand trial for his Holocaust crimes. Operation Finale [Chris Weitz, 2018] deals not with the life and crimes of Eichmann, or his life in Argentina, ${ }^{1}$ but the Mossad operation to capture him. Starring a high level cast including Oscar Isaac as Mossad agent Peter Malkin and Ben Kingsley as Eichmann, the film is splendidly acted by all cast, including a serious role for the traditionally comic actor Nick Kroll. Isaac in particular delivers, capturing the internal struggle of a man who lost his sister and her children in the Holocaust but who has to come face to face with the architect of his family's death and try to extract information - and a signature - from him.

The film starts with the tip received by Mossad from a Holocaust survivor living in Argentina. Lothar Hermann's daughter Silvia was dating a German boy, Klaus, who lived with his 'uncle', Ricardo Klement. But Hermann recognises Klement as Eichmann, and reports this to Mossad. What follows is the most gripping part of the film: the operation to confirm Eichmann's identity and capture him. It is enthralling because the Mossad team has to identify Eichmann without tipping him off and risking him fleeing. Eichmann is identified by photos taken by one of the agents from a bag, from which the agency compares photos and determines that his ears are the same. The operation then turns to the capture. Eichmann is a man of habit and timeliness, taking the bus to and from work every day at the same time. He is ultimately captured by the team as he walks from the bus stop to his house, put into a car, drugged and taken to a safe house.

After the capture, the movie slows significantly, dragging out the 10 days during which the team had to hold Eichmann in a safe house before they could remove him from Argentina. In this time, the Israeli government requires a signature from Eichmann demonstrating his agreement to go to Israel and stand trial. While some agents try intimidation tactics, Malkin tries the far more effective technique of creating rapport with the prisoner, eventually securing Eichmann's signature. It is this technique that creates conflict for Malkin, having 'ordinary' conversations with the man who engineered his family's death.

In the film, during this time, Klaus is collaborating with Argentinean police to hunt the Mossad team, a scenario which seems highly unrealistic (that a teenage boy would head up his own police hunt squad?) - and in fact, this did not happen. In the film, the team are almost caught, all deserting the safe house at the last minute, barely evading Klaus' hunting squad. The agents, with Eichmann, then head to the airport. Eichmann had to be snuck out of Argentina, so this is done with Eichmann in the guise of an El Al pilot, flying a plane of Israeli diplomats back to Israel after visiting Argentina for its 150th Independence Day celebrations. Almost all the team boards

${ }^{1}$ For a recent film on Eichmann in Argentina, see María L. Minassian, “Film Review: El Vecino Alemán (The German

Neighbor)," Genocide Studies and Prevention 12, no. 3 (2018), accessed March 16, 2019, Doi: 10.5038/1911-9933.12.3.1637.

Melanie O'Brien. “Film Review: Operation Finale" Genocide Studies and Prevention 13, 3 (2019): 178-180. @2019 Genocide Studies and Prevention.

https://doi.org/10.5038/1911-9933.13.3.1683 
the plane, and they are ready to go, but the plane's departure is delayed at the last minute, risking Eichmann being reclaimed by Klaus and his police squad. Malkin has to run back to the airport to file papers that had been removed by a Nazi, and at the very last minute, the plane takes off with Eichmann on board.

The film closes with the trial of Eichmann, with the agents played by Isaac, Kroll and Mélanie Laurent all present. We learn that Eichmann was executed in 1962, and that Malkin kept quiet about his role in the operation until his mother's death, when he told her that he had avenged his sister and captured Eichmann.

Overall, the film is very close to the reality of the operation. The few cinematic licences taken are that there was no love interest between Malkin and Laurent's doctor character, who was in reality a male doctor; there was no hunting squad of police with Klaus Eichmann; and there was no last-minute hold up of the plane taking off - it took off without a hitch, heading to Israel. Interestingly, it is the created scenes which are the least gripping and do feel like they do not fit; for example, the love story between Malkin and Laurent's agent/doctor are unnecessary and add nothing to the story.

Apart from that, the details are accurate, down to the fact that Malkin wore gloves when capturing Eichmann because he didn't want to touch Eichmann. Scenes were filmed in the original locations in Argentina (e.g. the actual cinema where Silvia met Klaus). In this regard, it is an excellent film to use in an educational context, being largely true to the facts and context of the operation. It also weaves in the psychological challenges for even highly trained intelligence agents when dealing with génocidaires: the internal struggle and temptation to simply execute the prisoner out of revenge for the deaths of their families and the 6 million Jews, rather than return him to face trial. We see Malkin struggling, picturing Eichmann's direct involvement in his sister Fruma's death. The temptation is real and at times a too-easy option, but ultimately the team supports each other and ensures that they do not stoop to the Nazis' level, but rather, apply rule of law and return Eichmann to face trial for his crimes. In his book about the operation, Malkin speaks of them as "professionals" who "realized the best revenge was getting him [to Israel]... that the point of this thing wasn't just an eye for an eye but justice." ${ }^{2}$

It is a shame that the film did not touch more upon the aspect of the trial that dealt specifically with Eichmann's capture. While Eichmann's trial is of course notable for being the (domestic) trial of a high-ranking Nazi who contributed substantially to the Holocaust, ${ }^{3}$ in the legal world it is also renowned for its significant contribution to jurisprudence on jurisdiction. There were two issues of jurisdiction in the case: one, universal jurisdiction (prosecuting someone for crimes committed in a different country); and two, whether it is legal to exercise jurisdiction over someone who was kidnapped from another country. This second head of jurisdiction is obviously highly relevant to the film's subject matter, as it raises the question of the legality of the very operation that is the focus of the film. Eichmann's defense contended that Israel had violated international law by kidnapping Eichmann. The issue was even addressed by the United Nations Security Council, which deftly sidestepped the controversy by declaring it an issue between Israel and Argentina, requesting Israel to make reparations to Argentina, and encouraging friendly relations between the two countries. ${ }^{4}$ Ultimately, the Israeli court was never going to allow Eichmann a loophole through which to escape trial and punishment, and so it was decided that, regardless of how a defendant was obtained, once

\footnotetext{
2 Peter Z. Malkin and Harry Stein, Eichmann in My Hands (New York: Open Road Integrated Media, kindle version 2018), (first published 1990), Chapter 24.

${ }^{3}$ And of course, for producing the famous book by Hannah Arendt, Eichmann in Jerusalem: A Report on the Banality of Evil (New York: Penguin Books, 1963).

${ }^{4}$ United Nations Security Council, Resolution 138, June 23, 1960 (UN Doc. S/RES/138). The matter was amicably closed between the two countries, undoubtedly because Argentina could hardly create an international incident over someone who had committed crimes in the Holocaust.
} 
he was in custody, he could be tried. ${ }^{5}$ Malkin does not touch of this in his book, but it can only be imagined that the appeal against jurisdiction based on their own actions would have affected the Mossad team members; another psychological battle for those involved, which would have been interesting to see portrayed on screen.

Operational Finale is available on Netflix, opening access to the story of Eichmann's capture to a substantial audience worldwide. Netflix is available worldwide (except China, North Korea and Syria), ${ }^{6}$ and Netflix specifically promoted this film; thus the distribution of Operation Finale as a form of Holocaust education is very effective, particularly given that it stars the popular and very prominent Star Wars ${ }^{7}$ actor, Oscar Isaac. In this regard, along with Schindler's List [Steven Spielberg, 1993], based on audience reach, this is surely one of the most impactful Holocaust films. While it may not tell the story of the Holocaust itself, the capture of Eichmann (and other war criminals and génocidaires) is part of the broader process of genocide, a significant element of survivors' recovery through seeing justice done to the perpetrators of a genocide in which they lost family, community and a significant part of their group, however that may be defined. Thus, bringing to film the stories of the people who bring perpetrators of atrocities to justice is vital. It is also inspirational, likely influencing the next generation to be part of the intelligence and justice mechanisms that contribute to punishment of perpetrators and consequently deterrence of future atrocities.

Title of the Film: Operation Finale; Director: Chris Weitz; Producers: Oscar Isaac, Brian KavanaughJones, Fred Berger; Screenplay: Matthew Orton; Cinematography: Javier Aguirresarobe; Film Editor: Pamela Martin; Sound Designer: Scott Hecker; Music: Alexandre Desplat; Cast: Oscar Isaac, Ben Kingsley, Mélanie Laurent, Lior Raz; Country: United States; Languages: English/Spanish/ French/German; Year of Production: 2013; Production Company: MGM/Automatik; Duration: 122 minutes. Available on Netflix.

\footnotetext{
${ }^{5}$ This was not unprecedented, however, as the court made reference to cases from other jurisdictions including England, in which this rule was applied; Attorney General v Adolf Eichmann, District Court of Jerusalem, Criminal Case No. 40/61, Judgment, 11 December 1961; see also Attorney General v Eichmann, 36 ILR 277 (1968) (Supreme Court of Israel 1962).

${ }^{6}$ Netflix, "Where is Netflix available?” Accessed March 16, 2019, https://help.netflix.com/en/node/14164.

${ }^{7}$ Star Wars: Episode VII- The Force Awakens, directed by J.J. Abrams (Burbank, CA: Lucasfilm Ltd, 2015); Star Wars: Episode VIII- The Last Jedi, directed by Rian Johnson (Burbank, CA: Lucasfilm Ltd, 2017).
} 